\title{
ENIGE BESCHOUWINGEN OVER DE BETEKENIS VAN HET ACCOUNTANTSBEROEP VOOR DE VERWEZENLIJKING VAN DE DOELSTELLINGEN VAN DE EUROPESE GEMEENSCHAP VOOR KOLEN EN STAAL
}

\author{
door Drs L. J. M. Roozen
}

\begin{abstract}
"Het zijn de instellingen, die de betrekkingen tussen de mensen beheersen; zij zijn de waarlijke peilers van de beschaving"'. (Jean Monnet)
\end{abstract}

\section{Inleiding.}

"Sedert Augustus jongstleden (1952) bestaat in het Westen van het door nationale grenzen en souvereiniteiten verbrokkelde continent de Europese Gemeenschap voor Kolen en Staal, welker taak het is op een beperkt, doch hoogst belangrijk terrein het lot van Duitsland, België. Frankrijk, Italië, Luxemburg en Nederland aaneen te smeden.

De Gemeenschap strekt zich uit van Hamburg tot Napels en van Brest tot Venetië, over alle Europese gebieden van deze zes landen. Op deze gebieden zullen slechts voor twee industrieën nl. de kolen- en staalindustrie door de oprichting van de Gemeenschap en door de werkzaamheden van de Hoge Autoriteit de grenzen, dounerechten, contingenten, discriminaties en beperkende practijken worden opgeheven, en zal een gemeenschappelijke binnenlandse markt van 155 millioen verbruikers tot stand komen, welke even groot is als die van de Verenigde Staten en die van de Sovjet-Unie. Voor deze sectoren (kolen en staal) is immers bij overeenstemmend besluit van de Parlementen een deel van de souvereine bevoegdheden en verantwoordelijkheden van de deelnemende Staten overgedragen aan de instellingen van deze Gemeenschap, welke aldus de eerste supra-nationale instellingen van Europa zijn".

Aldus luidt de aanhef van de uiteenzetting van de Hoge Artoriteit (H.A.), het uitvoerend orgaan van de Europese Gemeenschap voor Kolen en Staal (E.G.K.S.), omtrent de algemene toestand der Gemeenschap bij de indiening van de eerste begroting (over 1953).

Inmiddels is ook verschenen, het eerste algemene verslag van de H.A. aan de Gemeenschappelijke Vergadering (het parlement van de E.G.K. S.). over de periode 10 Auqustus 1952 tot 12 April 1953. 1)

Deze en andere publicaties van de E.G.K.S. en die in andere tijdschriften en dagbladen. hebben mijn besef doen groeien, ontstaan bij de bestudering van het Verdrag tot oprichting van de Europese Gemeenschap voor. Kolen en Staal 2), dat deze vrij-makende maatschappelijke ontwikkeling eveneens wijde perspectieven opent voor de in het vrije beroep werkzame accountants.

De bedoeling van deze beschouwing is, voor dit vraagstuk de belang-

1) Alle publicaties van de Gemeenschap, in een Nederlandse vertaling, zijn verkrijgbaar bij de Staatsdrukkerij en Uitgeversbedrijf te 's-Gravenhage, w.o. een regelmatig verschijnend Publicatieblad, bevattende de reglementen, algemene beschikkingen en andere algemene beraads!agingen van de instellingen der E.G.K.S.

2) Eveneens verkrijgbaar bij de Staatrdrukkerij. 
stelling te wekken van allen, die ermede te maken hebben, d.w.z. niet alleen van de accountant zelf, doch ook van allen, wier belangen of functie door het Verdrag worden beïnvloed, in het bijzonder de leiders van de circa 400 bedrijven, welke onder het gezag van de H.A. vallen en de functionarissen bij de Gemeenschap. Deze dubbele doelstelling brengt mede, dat ik zowel aandacht zal schenken aan de inhoud en de practische werking van het Verdrag, in het bijzonder t.b.v. mijn vakgenoten, als aan enkele principiële problemen aangaande de functie van de openbaar accountant, waarmede de laatstgenoemde groep, naar het mij voorkomt, in dit verband wordt geconfronteerd. Uit overwegingen van doelmatigheid begin ik met het laatste.

2. Enige vraagstukken aangaande maatschappelijke betekenis van het accountantsberoep.

\section{a. De deskundigheid van de accountant.}

Deze ligt in de eerste plaats en voornamelijk op het terrein van de bedrijfseconomische vraagstukken. Zulks houdt verband met het feit dat hij zijn nader te bespreken functie in hoofdzaak vervult in dat deel van het maatschappelijke verkeer, hetwelk bestaat in de organisatie van de voortbrenging in ruime zin.

De bedrijfs-economische deskundigheid omvat met name de kostprijsbepaling, de financiering, de balanswaardering, de interne organisatie en de externe organisatie, benevens de toepassing van deze onderdelen bij de administratieve organisatie en bij de verificatie (zgn. ,contrôle").

b. De functie van de accountant.

De oorzaak of het doel van het optreden van de accountant in het maatschappelijk verkeer schuilt in de overal optredende en steeds weer terugkerende behocfte van personen en organen die aan dat verkeer deelnemen, aan het oordeel van iemand die onpartijdig is d.w.z. buiten de belangen van die personen of organen staat. De deskundigheid van zo iemand is slechts een conditie voor de vervulling van die functie, evenals dit het ceval is met de arbeidstaak (de werkzaamheden) van de accountant 3 ). Het wezen van de functie schuilt in de onpartijdigheid van het (deskundige) oordeel, op grond waarvan partijen daaraan een zodanige betekenis hechten dat het kan dienen om tot overeenstemming te komen.

Het ,instrument" waarmede de functie wordt vervuld is de accountantsverklaring, d.i. elke mededeling van een accountant (mondeling of schriftelijk). waarin deze een oordeel kenbaar maakt of waaruit zijn oordeel te kennen is (verg. R.v.A. art. 1, lid 1).

De functie is niet beperkt tot de zgn. adviserende functie, d.i. het geven van een oordeel, hetwelk niet of slechts gedeeltelijk is gebaseerd op een .onderzoek" in de strikte zin.

De adviserende zowel als de controlerende functie monden beide uit in een verklaring. Op beide soorten verklaringen is dan ook van toepassinq de voornaamste bepaling in het Reglement van Arbeid van het $\mathrm{Ne}$ derlands Instituut van Accountants (artikel 2, lid 2):

„De leden zijn gehouden hun arbeid op zodanige wijze te ver-

3) Van accountantswerkzaamheden is dan ook geen andere algemene omschrijving te geven dan: werkzaamheden, verricht door een accountant! Zie het Reglement van Arbeid van het Nederlands Instituut van Accountants (R.v. A.) - artikel 1 lid 2. 
richten, dat deze een deugdelijke grondslag vormt voor hun mededelingen omtrent de uitkomst van die arbeid".

\section{c. Het begrip "partijen".}

Dit begrip mag niet worden opgevat in de privaatrechtelijke betekenis. "Partij" is iedere persoon of elk orgaan die (dat) bij de voorstelling van een bedrijfs-economisch verschijnsel of de waardering van de betekenis van dat verschijnsel een bepaald belang heeft.

De belangen van verschillende partijen kunnen convergeren of divergeren ${ }^{4}$ ). Wanneer zij convergeren doch het individuele inzicht verschilt, speelt alleen de deskundigheid van de accountant een rol. Wanneer de belangen divergeren, krijgt de accountantsverklaring haar hiervoren geschetste essentiële betekenis.

Als divergerend wil ik ook beschouwen het belang van degene die rekening en verantwoording aflegt en het belang van hem aan wie de rekening ter goedkeuring wordt voorgelegd. Deze zienswijze vergemakkelijkt de analyse. Met „divergeren" wil ik natuurlijk niet zeggen, dat tussen deze belanghebbenden steeds verschil van mening moet bestaan.

Het is nog van betekenis op te merken, dat de belangen, waarmede de verklaring van de accountant verband houdt, op het tijdstip van het afleggen daarvan weliswaar kunnen convergeren, doch dat steeds de mogelijkheid bestaat, dat zij op een later tijdstip divergeren, of dat de verklaring later wordt benut ter overbrugging van andere, divergerende belangen.

\section{d. Intern accountant - extern (openbaar) accountant.}

Tot dusver is speciaal gedacht aan de extern accountant d.w.z. aan hem die zijn functie uitoefent in het vrije beroep.

Daarnaast zien wij interne accountants optreden dat zijn zij die in dienstbetrekking staan van een onderneming of ander orgaan. $Z_{i j}$ zijn niet onafhankelijk tegenover de leiding van die onderneming of van dat orgaan. Daarbij is niet gedacht aan een financiële afhankelijkheid, doch aan functionele afhankelijkheid d.i. een vervulling van de functie in de uitvoering van zijn werkzaamheden onder het gezag van genoemde leiding. Uit hoofde van deze afhankelijkheid kan de interne accountant niet buiten de organisatie waarvan hij deel uitmaakt, als onafhankelijk deskundige optreden. Buiten die organisatie kan niemand met zekerheid op zijn onpartijdigheid en dus op zijn oordeel "vertrouwen" 5 ).

In het kader van de voorgaande beschouwing is het interessant na te gaan of de functie van financieel commissaris ex artikel 78 lid 6 van het Verdrag, verenigbaar is met de functie van openbaar accountant.

Deze commissaris is belast met de verificatie van de eigen financiële rekening en verantwoording der verschillende organen van de Gemeenschap. $\mathrm{H}_{\mathrm{ij}}$ wordt benoemd door de Raad van Ministers d.z. de vertegenwoordiqers van de Hoge Verdragsluitende Partijen. Zijn onafhankelijkheid alsmede de onverenigbaarheid van zijn functie met enige andere werkzaamheid bij een instelling of dienst van de Gemeenschap, wordt

4) Dit onderscheid is niet nieuw. Het werd. voor zover ik mij kan herinneren, het eerst gemaakt door Prof. Dr J. R. M. van den Brink, destijds Minister van Economische Zaken, bij zljn verdediging van het wetsontwerp op de publiekrechtelijke bedrijfsorganisatie.

5) Opgemerkt zij hier, dat de term "vertrouwensman" in het accountantsheroep niet primair betrekking heeft op de geheimhoudingsplicht tegenover de cliënt (zoals bijvoorbeeld bij de arts), doch op het vertrouwen (de verwachting) van alle belanghebbenden nopens de deskundigheid en de onpartijdigheid van het oordeel van de accountant. 
uitdrukkelijk gesteld. Hij staat derhalve buiten het gezag van welk bestuursorgaan van de Gemeenschap ook.

Mijn conclusie is, dat deze functie door een openbaar accountant vervuld zou kunnen worden.

e. De openbaat accountant zogenaamd „opsporingsambtenaar"?

Hiermede is natuurlijk niet bedoeld dat de openbaar accountant in dienst staat van een overheidsorgaan; zulks ware een contradictie, - een onverenigbaarheid. Men gebruikt deze uitdrukking echter wel, zonder daaraan overigens enige misplaatste, denigrerende betekenis te hoeven hechten, wanneer men denkt aan een eenzijdig door een overheidslichaam aan een openbaar accountant verstrekte opdracht, waarbij deze met bepaalde opsporingsbevoegdheden zou worden toegerust. Wat hiervan te denken?

De openbaar accountant is "vertrouwensman" van het maatschappelijke verkeer. Hieruit vloeit voort dat hij steeds de vertrouwensman is van tenminste twee of meer partijen ${ }^{5}$ ).

Eén van deze partijen kan zijn een overheidsorgaan, waaronder ik wil verstaan elk orgaan dat een gemeenschappelijk (.,algemeen") belang behartigt, onverschillig of het een publiekrechtelijk orgaan is dan wel geschapen is door een privaatrechtelijke overeenkomst.

Wanneer daarbij is voorzien in de mogelijkheid van een onderzoek door een openbaar accountant (welke persoon dan ook) 6), zal een bepaalde openbaar accountant zijn persoonlijke aanwijzing alleen dân kunnen aanvaarden, indien beide (resp. alle) partijen met die persoonlijke aanwijzing instemmen. De ,tegenpartij" van het overheidsorgaan kan immers niet de aanwijzing van enige openbaar accountant (wie dan ook) weigeren, doch wel de aanwijzing van een bepaalde accountant.

De door partijen aangewezen openbaar accountant heeft geen enkele .,bevoegdheid" nodig: hij bepaalt zelf of de opdracht uit vaktechnisch oogpunt uitvoerbaar is en, zo dit laatste het geval is, dan bepaalt hij tevens de arbeid die nodig is om tot zijn onpartijdig oordeel te komen. Legt welke partij dan ook, aan die arbeid een belemmering in de weg. dan zal de accountant zich terugtrekken.

Wanneer niet uitdrukkelijk (bij wet of overeenkomst) is voorzien in de mogelijkheid van de inschakeling van een openbaar accountant, dan hangt het af van de feitelijke verhouding tussen partijen of zij tot vrije overeenstemming kunnen komen aangaande het gebruik maken van de huln van een openbaar accountant (wie dan ook). Een overheidsorgaan heeft dan meestal nog wel een stok achter de deur, bijv. de omdraaiing van de bewijslast en/of het onderzoek door een eigen (interne) accountants- of contrōledienst (artikel 86, laatste alinea van het Verdrag - zie hierna punt 5).

Is eenmaal een bepaalde accountant door beide (alle) partijen aangewezen, dan moet deze ook worden geacht het vertrouwen te genieten van beide (alle) partijen.

Bij het inachtnemen van een juiste procedure, waarbij zowel de vrijheid van het gecontroleerde bedrijf als de vrije beroepsuitoefening van de accountant wordt geëerbiedigd, zal de openbaar accountant dus nimmer als een ,opsporingsambtenaar", in de hiervoren bedoelde zin, kunnen worden beschouwd.

Ik trek hieruit deze m.i. belangrijke conclusie, dat de inschakelinq van de openbare accountants door een overheidsorgaan nimmer doelmatig, of

6) Vanzelfsprekend neem ik aan, dat hij een gekwalificeerd vakman is. 
zelfs voor die accountants aanvaardbaar zal zijn, wanneer zij gepaard gaat met, of gebaseerd is op, wettelijke bevoegdheden aangaande de wijze waarop de accountant zijn onderzoekingsarbeid zal verrichten.

Dit beginsel aanvaard zijnde, staat de mogelijkheid van de vervulling van elke specifieke functie, (mede) t.b.v. de overheid, voor de accountant open. De laatste moet echter zelf bepalen, of hij de opdracht met het oog op zijn deskundigheid en de vaktechnische uitvoerbaarheid, kan aanvaarden, en daarna, hoe hij de aanvaarde opdracht zal uitvoeren ${ }^{7}$ ).

\section{In welke opzichten het Verdrag behoefte schept aan de inschakeling van accountants.}

De E.G.K.S. heeft een eigen doel, neergelegd in artikel 2 en nader geconcretiseerd in artikel 3 van het Verdrag.

De formulering in de $2 e$ alinea van artikel 2 (,,de omstandigheden scheppen, die uit zichzelf de meest rationele verdeling van de productie op een zo hoog mogelijk peil verzekeren") houdt in een principiële erken ning van de positieve maatschappelijke betekenis ener vrije concurrentie en van de noodzakelijkheid van het initiatief en de verantwoordelijkheid der individuele bedrijven. In artikel 83 wordt nog eens afzonderlijk bevestigd, dat de oprichting van de Gemeenschap in geen enkel opzicht de regeling van de eigendom van de ondernemingen raakt. Daarnaast echter is artikel 2 tweede alinea de uitdrukking van de overtuiging dat de vrije concurrentie, aan zichzelf overgelaten, in haar tegendeel verkeert. Op deze overtuiging is het doel van de E.G.K.S. gebaseerd.

In overeenstemming met deze uitgangspunten geeft artikel 5 de nodige waarborgen tegen het meer ingrijpen in het beleid van de individuele bedrijven dan, gegeven de doelstelling van de E.G.K.S., strikt noodzakelijk is; dit "meer ingrijpen" wordt hierna kortheidshalve "dirigisme" genoemd (bij gebrek aan een meer objectief klinkende uitdrukking!). Het is belangrijk hierbij op te merken, dat artikel 5 als één der middelen om dirigisme te vermijden, noemt: "het verzamelen van gegevens". Reeds op deze plaats zij er de nadruk op gevestigd, dat dit middel slechts doeltreffend kan zijn, wanneer de belanghebbenden een redelijke waarborg hebben, dat de gegevens juist zijn.

Een ander middel tot vermijding van dirigisme, in artikel 5 genoemd. is de beperking van het administratieve apparaat van de organen der Gemeenschap. Deze richtlijn is mede van betekenis voor de keuze tussen een eigen accountantsdienst en het gebruik maken van de diensten van openbare accountants (dit wordt nog af zonderlijk besproken - zie punt 5).

De Hoge Autoriteit der Gemeenschap (H.A.) is volgens artikel 8 belast met de verwezenlijking van de doelstellingen der E.G.K.S. Daartoe geeft zij beschikkingen, die verbindend zijn in al hun onderdelen. doet zij aanbevelingen, die verbindend zijn t.a.v. de daarin gestelde doeleinden, doch die aan de bedrijven de keuze laten van de middelen, en geeft zij adviezen, welke niet verbindend zijn.

\section{In haar gezagsuitoefening bindt de H.A. zelf de bedrijven op be-}

7) In dit verband verwijs ik naar mijn opstel over de tot stand koming van een wettelijke regeling van het accountan sbe:oep in België, waarbij misverstand dienaangaande na grote moeilijkheden heeft geleid tot een wet, waarin de aard van de functies, alsmede de bevoegdheden van de accountant in het kader van de wettelijke bedrijfsorganisatie zijn omschreven, d.w.z. beperkt (dit opstel zal, naar ik verwacht, binnenkort in dit maandblad verschijnen). 
paalde onderdelen der bedrijfsvoering tot een bepaald beleid.

Deze beleidsvoorschriften hebben in hoofdzaak betrekking op:

a. Diverse soorten heffingen, nl.:

1. tot dekking van de eigen kosten der E.G.K.S.

2. tot dekking van de subsidies ter vervanging van werkgelegenheid (bij stillegging van bedrijven)

3. ter garantie van door derden verstrekte leningen en ter financiering van zelfverstrekte leningen

4. tot dekking van researchkosten (voor $1 \mathrm{t} / \mathrm{m} 4$ zie de artt. 49 en 50 )

5. een tijdelijke vereveningsheffing bij de kolenmijnen van die landen, waarvan de gemiddelde kostprijzen lager zijn dan het gemiddelde voor de Gemeenschap - zie Overeenkomst met betrekking tot de overgangsbepalingen, $\S 25$ )

De heffingen sub $1 \mathrm{t} / \mathrm{m} 4$ belopen jaarlijks ongeveer 50 millioen dollar $\left.{ }^{8}\right) . Z_{i j}$ worden berekend naar een door de H.A. bepaalde, gemiddelde opbrengstwaarde per ton vervaardigd product van elke soort ( 2 soorten steenkool, 4 soorten staal), na aftrek van de kosten van eigen verbruik van kolen resp. staal. De ondernemingen doen maandelijks, bij de betaling van de heffing, aangifte van de productie (Beschikking No. 2-52, art. 4). Deze aangifte is een rekening en verantwoording, welke voor verificatie in aanmerking komt. De gemiddelde waarde moet worden bepaald op basis van bedrijfsgegevens, welke eveneens voor contrōle in aanmerking komen. Wat het laatste betreft, zij opgemerkt, dat t.a.v.. de vereveningsheffing sub a 5 zelfs de belangen tussen groepen van ondernemingen divergeren, terwijl voorts de contrôle op de besteding van de verevenings-uitkeringen niet zonder betekenis is.

b. De mate en vorm van openbaar maken van prijsschalen en verkoopvoorwaarden voor de gemeenschappelijke markt (artikel 60, lid 2). Dit staat in verband met het verbod van incidentele prijsverlagingen en van discriminatie bij gelijksoortige transacties (artikel 60, lid 1). Op grond van artikel $8 \mathrm{zal}$ de H.A. $z$ ich er van willen vergewissen, dat de bedrijven zich ook aan de openbaar gemaakte condities houden.

c. In een uitgesproken crisisperiode: het invoeren van een stelsel van productiequota, op grondslag van de in samenwerking met de ondernemingen gemaakte studies, het in verband daarmede leggen van heffingen op overschrijdingen en verlenen van ondersteuningen bij onderschrijdingen (artikel 60, leden 1 en 2), alsmede de vaststelling van minimum-prijzen (artikel 61, sub b).

d. In een periode van ernstige schaarste: het opleggen van productieprogramma's (artikel 59, lid 2), alsmede de vaststelling van maximumprijzen (artikel 60, sub a), eveneens op basis van voornoemde studies.

In de gevallen sub $\mathrm{c}$ en $\mathrm{d}$ zal de H.A. voorzeker behoefte hebben aan een verificatie van de door de bedrijven overgelegde gegevens, met name inzake de kostprijzen. Het is van belang op te merken, dat de noodzakelijkheid van maatregelen. als bedoeld sub c en $\mathrm{d}$, in de practijk incidenteel en plotseling noodzakeliik zullen blijken te zijn. Wegens de omvang en de diepgang van de onderhavige onderzoeken, zou daarmede lange tijd gemoeid zijn, indien zij nog van de grond af aan moesten worden verricht. Aangezien de maatregelen, zodra zii eenmaal noodzakelijk blijken, geen lang uitstel zullen dulden, zal de H.A. permanent de beschikking

8) Rede van Jean Monnet voor de Gemeenschappelijke Vergadering op 12 Januari 1953.

mab blz. 19 
willen hebben over geverifieerde basisgegevens t.a.v. de kostprijzen, zodanig aangevuld, dat de einduitkomsten zonder veel onderzoekingsarbeid zullen zijn vast te stellen. Op deze wijze is het risico van een onuitvoerbare opeenhoping van accountantsarbeid ook practisch weg te nemen.

e. Bij gebleken prijsdiscriminatie door kopers (handelaren!): het verplichten tot zodanige verkoopvoorwaarden, dat de kopers zich verbinden de voorschriften van de H.A.. in acht te nemen en zo nodig, het opleggen van een verbod om aan bepaalde kopers te leveren.

Het is opmerkelijk, dat de meeste der voornoemde beleidspunten te beschouwen zijn als typische vraagstukken, welke zich voordoen bij de kartels, in welker kader de openbare accountants vaak zulke belangrijke. specifieke functies vervullen.

Hoewel het doel van de Gemeenschap veel ruimer is gesteld dan die van de privaatrechtelijke ondernemingsorganisaties en daardoor daaraan tot zekere hoogte zelfs tegengesteld is (zie II), zijn de gehanteerde middelen casu quo de practische bedrijfseconomische vraagstukken grotendeels dezelfde. In het bijzonder noem ik in dit verband de quotering (met het daaraan verbonden vraagstuk van de meting der capaciteit), de prijsregeling (met het annexe vraagstuk van de kostprijsberekening), de egalisatie van inkoops - of verkoopprijzen, alsmede de contrōle op de naleving. Zelfs de elementen van maximumprijs-niveau, van leveringsplicht en van rationalisatie zijn aan een kartelorganisatie waarin een verantwoord beleid wordt gevoerd, niet vreemd.

Deze vergelijking onderstreept de noodzakelijkheid ener verificatie van de gegevens, waarop de H.A. haar beleidsvoorschriften moet baseren. wil zij er zeker van zijn, dat met de gebruikte middelen het doel van de Gemeenschap wordt bereikt.

Als bewijs voor mijn stelling, dat dit alles geen "graue Theorie" is, maar dat integendeel verondersteld mag worden, dat het vraagstuk van de inschakeling van accountants langzamerhand in een acuut stadium begint te komen, moge ik het volgende vermelden.

De waardebasis per ton van de zes onderscheiden producten, voor de heffingen, zijn berekend op basis van de door de Hoge Autoriteit verzamelde ,statistische" gegevens (zie Beschikking No. 2-52).

Bij Beschikking No. 1-53 is besloten, dat de vereveningsheffing zal worden geheven bij de Duitse en Nederlandse kolenmijnen. In de considerans wordt uitdrukkelijk geconstateerd ,,dát de gemiddelde kostprijzen alleen in Duitsland en Nederland lager zijn dan het gewogen gemiddelde van de Gemeenschap.

Bij Beschikking No. 2-53 heeft een verdeling van schroot tussen Duitsland, Frankrijk en Italië plaatsgevonden, ter voorkoming van, ,ernstige verstoringen in de voorziening van de staalindustrie", met het oog op "het verschil tussen de prijs van het binnen de Gemeenschap ingezamelde schroot en die van het uit derde-landen geïmporteerde schroot".

De Beschikkingen Nos. $6 \mathrm{t} / \mathrm{m} 24-53$ regelen de vaststelling van maximumprijzen voor kolen. De considerans van No. 6 vermeldt: ,dat, teneinde verstoringen in de economie van de deelnemende Staten te voorkomen, het peil van de kolenprijzen binnen de Gemeenschap moet worden aangepast aan het peil thans voortvloeiende uit de maximumprijzen. welke in alle deelnemende Staten zijn vastgesteld ...... (enz.)".

Laatstgenoemde maatregelen waren dus nog slechts de consequentie van de bevoegdheidsovername van de nationale Regeringen. Op $12 \mathrm{Mei}$ 
1953 echter stelde de heer Blaisse, lid van de Gemeenschappelijke Vergadering, de vraag: „Bestaat bij de Hoge Autoriteit niet de indruk dat de maximumprijzen - gemiddeld of absoluut - op een te hoog niveau zijn vastgesteld?" De H.A. antwoordde o.a. dat .onder deze omstandigheden (een eerste fase) een verandering in het prijsniveau het gevaar van ernstige repercussies, zowel op de exploitatievoorwarden van de kolenindustrie als ${ }^{9}$ ) op de nationale econommieën van de deelnemende staten, zou medebrengen" (Publicatieblad 21 Juli 1953. blz. 158).

Bij Beschikking No. 28-53 stelde de H.A. maximum-(inkoops-)prijzen voor schroot vast, alsmede een handelsmarge voor schroot.

Bij Beschikking No. 29-53 keurde de H.A. goed de egalisatie van de kolenprijzen in Nederland.

Bij Beschikking No. 33-53 stond de H.A. toe de instelling van een egalisatiefonds voor schroot uit derde-landen, door de ruwijzer- en staalproducerende ondernemingen van de Gemeenschap. Daarbij bepaalde zij, dat zij .te allen tijd door een door haar hiermede belaste functionaris of accountant ${ }^{9}$ ) het beheer en de boekhouding van het Egalisatiefonds voor ingevoerd schroot (kan) laten controleren".

Deze opsomming van practische vraagstukken, welke reeds zijn gere$z e n$, is stellig niet volledig. $Z_{i j}$ dienen slechts ter illustratie van het voorafgaande.

Ik zou echter bepaald tekortschieten, wanneer ik enkele passages uit de verslagen van de $H$.A. hier onvermeld liet.

In par. III: ..Het prijzenvraagstuk" van de .Uliteenzetting over de Toestand van de Gemeenschap" d.d. 10 Januari 1953, wordt o.a. opgemerkt:

„Bij het onderzoek naar de prijzen waarmede de Hoge Autoriteit een aanvang heeft gemaakt, moeten twee groepen van factoren zorgvuldig worden onderscheiden:

- enerzijds bepaalde kostprijsbepalende ${ }^{9}$ ) factoren welke verband houden met de algemene exploitatievoorwaarden van de ondernemingen, d.w.z. het loonpeil, de aanschaffingsprijs der grondstoffen en de technische factoren welke, gezien de organisatie en staat waarin de bedrijfsuitrusting zich bevindt, bepalend zijn voor het grondstoffen- en energieverbruik en het aantal arbeidsuren dat aan de vervaardiging van de producten moeten worden besteed. (enz.)"

lets verder wordt gesproken over de afschrijvingen: „......... gaat de Hoge Autoriteit na op welke wijze de afschrijvingsberekeningen in de verschillende landen van de Gemeenschap vergelijkbaar gemaakt kunnen worden" ........, Uit het eerste onderzoek is gebleken, dat de bestaande verschillen van tweeërlei aard zijn:

1. enerzijds wordt de scheiding tussen de op rekening .,Kapitaalgoederen" geboekte en vervolgens afgeschreven posten en de op , lopende uitgaven" geboekte posten ${ }^{9}$ ) in het ene land anders dan in het andere. Het is dan ook noodzakelijk een onderzoek in te stellen naar de juistheid van sommige veel gehoorde beweringen over verschillen tussen de in de prijzen ingecalculeerde afschrijvingen, terwijl tevens een nader onderzoek gewenst is ten aanzien van de ontoereikendheid van bepaalde verkoopprijzen in verhouding tot de productiekosten; 9 )

9) Cursivering van mij. R. 
2. anderzijds verschillen de afschrijvingsmethoden naargelang van de boekhoudingsvoorschriften en de fiscale bepalingen in deze.

Het aldus aangevangen onderzoek zal worden voortgezet nadat de nodige inlichtingen verzameld zijn op grond van de vragenlijsten, die door de werkgroep zijn samengesteld. Met behulp van dit onderzoek moet het mogelijk worden de starheid van de prijzen te beoordelen ......... Voorts moet dit onderzoek bijdragen tot de analyse van de financieringsmiddelen welke voor investeringen ......... beschikbaar zijn. Bovendien zal het een hulpmiddel zijn bij het vormen van een oordeel omtrent het wenselijke prijspeil zoals gedefinieerd in artikel 3, c van het Verdrag" 10).

In het ".Algemeen Verslag" over de periode 10 Augustus 1952 tot 12 April 1953, trof ik de volgende passages aan.

(Aangaande de vereveningsheffing:) ,Zelfs indien men de kostprijs in de landen waar deze verondersteld wordt het laagst te zijn, zo ruim mogelijk schat, en voor de landen waar de kostprijs verondersteld wordt het hoogst te zijn, zo laag mogelijk, kunnen twee groepen duidelijk worden onderscheiden: enerzijds Duitsland en Nederland met een kostprijs welke uitgesproken onder het gewogen gemiddelde van de Gemeenschap ligt. en anderzijds België, Italië, Frankrijk en het Saargebied met een hoge gemiddelde kostprijs.

Indien echter de verhouding tussen de kostprijzen zich zou wijzigen 11) dan zou deze eenvoudige methode welke alleen van waarde is zolang er belangrijke verschillen bestaan, door een nauwkeurige raming vervangen dienen te worden, welke in het bijzonder door een werkgroep voor de vergelijkbaarheid van de afschrijvingsvoorzieningen wordt voorbereid" (blz. 58).

Wat het onderzoek naar de afschrijvingen betreft, worden op blz. 103 de volgende conclusies vermeld.

,a. Wat betreft de scheiding tussen de posten, welke op actief of ten laste van de exploitatierekening worden geboekt, kan bij de boeking van bepaalde uitgaven een grote mate van overeenstemming worden vastgesteld. Als voorbeeld moge genoemd worden de eerste uitrusting van een bedrijf met gereedschap en materieel of werkzaamheden in verband met de invoering van een nieuwe productietechniek. Dergelijke uitgaven worden steeds op actiefrekening geboekt. Het probleem kon dus tot het onderzoek van een aantal twijfelgevallen worden beperkt, waaronder met name de vervanging van bestaande installaties valt: juist in deze groep van investeringen treft men van land tot land grote verschillen aan. $\mathrm{Te}-$ vens wordt bevestigd, dat alleen (? R.) in deze groep een zekere mate van flexibiliteit kan optreden, niet alleen van onderneming tot onderneming, doch ook van jaar tot jaar. Teneinde een duidelijker begrenzing van deze groep mogelijk te maken, is thans een tweede onderzoek ter zake van de kolenmijnen gaande; dit onderzoek omvat de studie van de indeling en de toegepaste afschrijvingspercentages voor elke post afzonderlijk.

b. Het doel van dit tweede onderzoek is tevens het relatief belang van

10) Volg̣ens laatstgenoemde bepaling moeten de instellingen van de Gemeenschap ........ waken voor een zo laag mogelijke prijsstelling ......... (waarbij) ruimte gelaten moet worden voor de noodzakelijke afschrijvingen en voor een normale beloning van de geïnvesteerde kapitalen". (Cursiveringen van mij. R.)

11) En hiernaar wordt gestreefd door aanpassing van lonen, belastingen, rationalisatie en eventuele stillegging. $\mathrm{R}$. 
de afschrijvingen in verhouding tot de andere factoren van de kostprijs ${ }^{9}$ ) van de kolen nader te bepalen. Het bleek inderdaad noodzakelijk de grootst mogelijke aandacht aan deze berekening van de kostprijs te besteden, aangezien de fiscale voorschriften met betrekking tot de afschrijvingen van belang $z$ ijn voor zover $z i j$ het beleid van de ondernemingen beïnvloeden. Het mag reeds als vaststaand worden aangenomen, dat binnen de nationale kolenmijnen een zekere uniformiteit in de kostprijsberekening bestaat (behalve voor Nederland). De basiswaarden benaderen de vervangingswaarde of staan in een bepaalde verhouding tot de aankoopwaarde, terwijl het afschrijvingstempo constant is."

Ik waag de veronderstelling, dat zich t.a.v. de kostprijsberekening nog wel andere belangrijke vraagstukken zullen voordoen, bijvoorbeeld wat betreft de scheiding tussen constante en variabele kosten, en de invloed van de capaciteit op de constante kosten per eenheid product.

II. Een ander deel van de gezagsuitoefening der H.A. heeft betrekking op het waken voor de naleving. zowel van de door haarzelf gegeven voorschriften (zie I), als van de bepalingen in het Verdrag, welke de bedrijven rechtstreeks binden.

Wat het laatste betreft is reeds gesproken over artikel 60, lid 1 (zie I sub b); vermeld zij nog artikel 65 , in het algemeen inhoudende een verbod voor de bedrijven, om onderlinge kartelovereenkomsten aan te gaan. De H.A. kan uitzonderingen hierop toestaan (dus omgekeerde procedure als de Nederlandse kartelwetgeving, waarbij vrijheid bestaat met de mogelijkheid van Regeringsingrijpen). Er is reeds een groot aantal - ruim zestig 12) - verzoeken daartoe ingediend. De daarbij overgelegde gegevens zullen waarschijnlijk geheel of gedeeltelijk in aanmerking komen voor verificatie.

Interessant is nog te vermelden een uitspraak van de H.A., dat de reden voor privaatrechtelijke marktregelingen voor de onder de Gemeenschap vallende ondernemingen is vervallen, omdat de (verantwoorde) doelstelling daarvan a.h.w. is opgenomen in die van de Gemeenschap:

Op 12 Mei 1953 stelde de heer Blaisse de vraag: „Onderschat de H.A. niet de onmiskenbare betekenis van sommige industriële en andere overeenkomsten, die in het verleden bij productie en handel in sterke mate hebben bijgedragen tot een goed functionneren van de markt tot het vaststellen van lage prijzen en tot stabiliteit?"

De H.A. antwoordde dat de ,rechtvaardiging" van ,afspraken ...... als middel om gevrijwaard te zijn tegen bepaalde risico's ...... vervalt op grond van het Verdrag, aangezien het Verdrag aan de instellingen van de Gemeenschap, en uitsluitend aan deze, het hanteren van de eventueel noodzakelijk blijkende beveiligingsmaatregelen heeft toevertrouwd, zonder dat de instellingen dit aan een overeenkomst tussen de producenten kunnen overlaten". (Publicatieblad 21 Juli 1953, blz. 161).

III. De H.A. legt bij overtredingen zelf boeten op, waarvan de hoogte meestal samenhangt met de economische waardering (in geld) van het gepleegde, strafbare feit of van een ander economisch gebeuren.

Als voorbeeld noemen wij artikel 58, lid 4, waarin de overtreding van productie-quotering (in een crisisperiode) kan worden gestraft met "ten hoogste een bedrag gelijk aan de waarde van de ongeoorloofde productie" en artikel 59, lid 7, waaris het niet uitvoeren van een opgelegd produc-

12) Volgens $\mathrm{Mr}$ H. H. Maas in Sociaal-Economische Wetgeving, November 1953, blz. 633 .

m a b blz. 23 
tieprogramma (bij ernstige schaarste) kan worden beboet met „een bedrag van ten hoogste het dubbele van de waarde van de voorgeschreven producties of leveringen". Kan de overtreding zelf niet worden gewaardeerd, dan wordt een andere grondslag aangehouden, zoals in artikel 65 . lid 5, waarin bij overtreding van het verbod tot kartelvorming, of bij het opzettelijk in dit verband verstrekken van onjuiste inlichtingen, een boete of een dwangsom kan worden opgelegd, evenredig aan de omzet.

$\mathrm{B}_{\mathrm{ij}}$ voorkomende gevallen zouden deze waarderingen of grondslagen eveneens voor verificatie in aanmerking kunnen komen.

Uit het voorgaande blijkt wel, dat het op rationele wijze gebruik maken van accountantshulp niet beperkt is tot een bijstand bij de zorg van de H.A. voor de naleving van haar voorschriften en die, welke rechtstreeks uit het Verdrag blijken (zie II). Het gaat om de betrouwbaarheid van alle bij de $H$.A. ingediende gegevens, waarop de $H$.A. haar beleid in algemeenheid (zie I t/m III) moet baseren.

Hiermede is wel de omvang van het onderzoekingsgebied voor de accountant, doch bij lange niet de volledige betekenis van zijn deskundig en onafhankelijk oordeel over de verschijnselen binnen dat gebied, c.q de voorstellingen daarvan door belanghebbenden, aangegeven.

De E.G.K.S. heeft een zeer complexe, uitgebalanceerde structuur. waarin de H.A. als centraal beleidsorgaan ook zelf meermalen in de positie is, dat zij gegevens overlegt, ter staving van haar voorstellen of ter motivering van haar beslissingen.

a. De H.A. moet jaarlijks een algemeen verslag publiceren (art. 17). hetwelk door de Gemeenschappelijke Vergadering moet worden goedgekeurd. Afkeuring met $2 / 3$ van de stemmen betekent het aftreden van de leden der H.A. (art. 24). Voorts moet de H.A. de door of in de Vergadering gestelde vragen beantwoorden.

Uit het voorgaande is wel in enkele voorbeelden gebleken, dat deze bepalingen geen dode letters zijn. Integendeel, de E.G. K. S. streeft een publiciteit na, welke zelfs over haar organen heen, zich richt tot ieder belangstellende. Mijn bronvermeldingen zijn er het bewijs van.

Zowel het afleggen van verantwoording door de H.A., als het déchargeren door de Vergadering, is uiteraard slechts mogelijk, wanneer de vraag naar de juistheid van de in het verslag vermelde gegevens bij voorbaat buiten discussie kan blijven.

b. De H.A. moet overlèggen en inlichtingen uitwisselen met de Raad (van Ministers), teneinde haar beleid en dat van de nationale Regeringen op elkander af te stemmen. De Raad kan de H.A. verzoeken om over bepaalde voorstellen advies uit te brengen (art. 26).

Dit overleg op zulk een hoog niveau kan niet gehinderd worden door twijfel omtrent de juistheid der gegevens.

c. De H.A. kan het Raadgevend Comité (producenten, werknemers, verbruikers en handelaren) raadplegen (artt. 18-19). In de meeste gevallen is zij daartoe zelfs verplicht.

De kennelijke bedoeling hiervan is, elke schijn of practijk van dirigisme weg te nemen. Ook hier mag de daarvoor noodzakelijke sfeer van redelijk overleg niet worden vertroebeld door twijfel of verschil van mening over de uitgewisselde gegevens.

d. Het Hof van Justitie doet uitspraak op elk beroep van een direct belanghebbende partij bij het Verdrag (één der organen van de E.G.K.S.

m a b blz. 24 
dan wel één of meer der aan het Verdrag onderworpen ondernemingen) tot nietigverklaring van een beslissing door een gezagsorgaan van de E.G.K.S. genomen.

Ook hierbij kunnen feiten in het geding worden gebracht, welke verificatie behoeven.

Wanneer wij hiervóór stelden, dat het onderzoekingsgebied voor de accountant reeds was bepaald, bedoelden wij, dat het steeds zal gaan over de bedrijfseconomische verschijnselen binnen de ondernemingen of rakende haar onderling verkeer. De verificatie van deze zelfde verschijnselen (omzetten, kostprijzen, prijzen en condities, organisatorische verhoudingen, enz.) heeft haar nut, niet slechts in de verhouding tussen H.A. en bedrijven, doch tegelijk voor de verhouding tussen genoemde „partijen" en de andere E.G.K.S.-organen. De contrôle door en de adviezen van de accountant op het gebied van zijn deskundigheid (zie 2 sub a) heeft een accumulerend nut.

\section{Vermijding van doublure door inschakeling van de bedrijfsaccoun- tants.}

Onder "bedrijfsaccountants" wil ik verstaan: de public accountants, die bij de onder de E.G.K.S. ressorterende ondernemingen de jaarrekening verifiëren en certificeren, teneinde de décharge van het bestuur door de eigenaren (meest aandeelhouders) mogelijk te maken en meer in het algemeen voor het verschaffen van zekerheid aan het „publiek”, omtrent de juistheid van die jaarrekening.

Het staat wel vast, dat deze bedrijfsaccountants reeds op grond van hun bovengenoemd onderzoek zonder meer beschikken over een aantal van de onder punt 3 genoemde gegevens, met name die, welke betrekking hebben op de hoeveelheden en waarden van inkopen, verbruik en afzet. Daarenboven kunnen zij binnen het raam van de door hen in een vast verband sluitend bevonden gegevens, en dus zonder veel extra arbeid, andere gegevens vaststellen, met name de kostprijsgegevens.

Het ligt dus voor de hand, dat de bedrijfsaccountants het eerst in aanmerking komen bij de inschakeling van public accountants op de hiervoren bepleite wijze, waarbij wij er nog eens de nadruk op leggen, dat deze accountants de opdracht slechts zullen kunnen aanvaarden, wanneer zowel de H.A. als de betrokken onderneming daarmede instemmen.

Het komt mij voor, dat hiermede een grote doublure aan onderzoekingsarbeid kan worden vermeden, met een evenredige mogelijkheid ener besparing van kosten niet alleen, doch ook van tijd. Wat het laatste betreft heb ik er reeds op gewezen, dat het onderzoek in vele gevallen geen nut zal hebben, wanneer de verklaring niet op zeer korte termijn kan worden versterkt (zie punt 3 , sub I d).

Het spreekt vanzelf, dat deze organisatie van de contrōle alleen mogelijk is, indien en voorzover de bedrijfsaccountants gekwalificeerde en aan een doelmatige beroepstucht onderworpen vakmensen zijn. Op dit vraagstuk kom ik nog terug, doch ik wil er hier de conclusie aan vastknopen, dat de integratie van de kolen - en staalmarkten, en de uiteindelijke doelstelling van de volledige integratie voor alle producten en diensten tot één Europese markt, de schepping van de Europese accountant - van hoge vaktechnische bekwaamheid en onderworpen aan algemene beroepsregelen - tot een maatschappelijk desideratum van de eerste orde doet zijn. 
5. Een eigen contröle-dienst, gesteld tegenover de inschakeling van de public accountant (beider eigen mogelijkheden en beperkingen).

Wanneer bij de verificaties in het kader van de gemeenschap (zie 3) zou worden gestreefd naar het zoveel mogelijk inschakelen van accountants, werkzaam in het vrije beroep, dan is daarmede nog niet gezegd, dat een eigen contrôle-instantie van de H.A. overbodig zou zijn. Twee factoren spelen hierbij een rol.

In de eerste plaats kan het zijn, dat er onderzoekingen moeten plaatsvinden, waarbij de deskundigheid van de accountant niet vereist is, of waarvoor een deskundigheid wordt gevraagd die niet des accountants is. Onder deze factor wil ik ook rekenen de gevallen, waarin de openbaar accountant van oordeel is, dat hij door toepassing van zijn vaktechniek niet de zekerheid kan verwerven, welke nodig is om zijn oordeel te geven.

In de tweede plaats bestaat steeds de kans, dat een onderneming stelselmatig weigert, in de inschakeling van een public accountant toe te stemmen. ${ }^{13}$ ) In zo'n geval zal de H.A. zelf een onderzoek willen instellen.

Inderdaad voorziet het Verdrag in artikel 86 in ,functionarissen van de Hoge Autoriteit, die door haar met contrôle-werkzaamheden zijn belast" en die ,,beschikken ...... over dezelfde rechten en bevoegdheden. als door de wetgevingen van deze Staten aan ambtenaren van de belastingdiensten zijn verleend."

Het is merkbaar, en zelfs waarschijnlijk, dat aan het aldus gevormde contrôle-apparaat ook (interne) 14) accountants worden toegevoegd, teneinde van hun deskundigheid gebruik te maken.

Kan men nu de zaak omdraaien, en zeggen, dat door de instelling van een eigen contrôle-dienst, de inschakeling van public-accountants overbodig wordt?

In genen dele! Zulks blijkt uit het voorafgaande. Ik vat echter de argumenten nog eens samen.

a. Er ontstaat dan een grote doublure van onderzoekingsarbeid, met de daaraan verbonden vermeerdering van kosten en tijd (zie 4).

b. De functionele plaats van dit apparaat belet het, de bredere accumulerende functie binnen de gehele organisatie van de E.G.K.S. te vervullen, bijv, ter décharge van de H.A. door de Gemeenschappelijke. Vergadering, als bedoeld in artikel 24 van het Verdrag (zie punt 3).

c. Denkbaar ware nog het instellen van een zelfstandig accountantsorgaan, onder de leiding van een onafhankelijk functionaris, zoals bedoeld in artikel 78, lid 6, van het Verdrag. Deze functionaris zou. zoals reeds eerder (sub $2 \mathrm{~d}$ ) is opgemerkt, functioneel dezelfde positie als een openbaar accountant innemen. Afgezien echter van het bezwaar sub a, meen ik, dat het een groot en principieel verschil uitmaakt, of zulk een functionaris de eigen organen van de E.G.K.S. controleert (zoals in artikel 78, lid 6 is omschreven), dan wel de onder de E.G.K.S. vallende ondernemingen. Immers: de mogelijkheid van een vrije keuze van de persoon van de accountant komt voor de onderneminqen te ontbreken. Deze ondernemingen zullen de formeel onafhankelijke accountantsdienst terecht blijven zien als een orgaan, zo niet van de H.A. dan toch van de E.G.K.S. ${ }^{15}$ ).

13) Zie punt $2 \mathrm{e}$, waaronder ik betoogde, dat de public accountant zich dan zal moeten terugtrekken.

14) "Intern" in de algemene betekenis van: in dienstbetrekking staande.

15) Vergelijk mijn beschouwingen over ..De accountant-ambtenaar en de overheidsvoorschriften met betrekking tot de aeheimhonding" (MAB 1948 - No. 10) in het bijzonder het afgezonderde gedeelte op blz. 302/303.

m a b blz. 26 
d. Een eigen contrôle-apparaat, belast met alle verificaties, zou zulk een omvang vereisen - mede i.v.m. beschikbaarheid voor spoedopdrachten -. dat moeilijk meer gesproken zou kunnen worden, zoals in artikel 5 laatste alinea van het Verdrag, van ,een beperkt administratief apparaat."

\section{Handhaving van de scheiding tussen bestuurdersverantwoordelijkheid en accountantsverantwoordelijkheid.}

Aangezien het beleid van de H.A. voornamelijk betrekking heeft op of voert tot het ontstaan van bedrijfseconomische verschijnselen, en de ingeschakelde openbaar accountant tot taak zou hebben sommige dezer verschijnselen vast te stellen, bestaat er steeds een gevaar van vermenging van de twee verantwoordelijkheden.

Onder geen omstandigheid mag de inschakeling van de accountant er toe leiden, dat deze door eigen interpretaties van de ontvangen opdracht of door het zelf kiezen van economische maatstaven, het beleid van de H.A. op détailpunten overneemt.

Bezien vanuit de gezichtshoek van het accountantsberoep is er nog een bijzonder gevaar verbonden aan het direct deelnemen door de accountant aan het beleid van de H.A.: dit zou de onbevangenheid van zijn oordeel (met name over het resultaat van het beleid) antasten; hij zou bij de waarneming van dat resultaat niet meer onpartijdig te achten zijn.

Deze gevaren zijn te vermijden door de volgende richtlijnen aan te houden.

a. Het object en de strekking van de aan de accountants op te dragen onderzoekingen zouden door de H.A. zodanig moeten worden geformuleerd, dat de accountants bij de uitvoering van de opdracht niet zelf beslissingen meer behoeven te nemen, welke naar haar aard aan de H.A. zijn voorbehouden. Dit houdt tevens in, dat de accountant, wanneer tijdens zijn onderzoek in dit opzicht leemten in de opdracht blijken, met de H.A. overleg pleegt, alvorens het onderzoek voort te zetten.

b. De adviezen (in de meer beperkte zin - zie punt 2b) van de accountant moeten meer gericht zijn op een weergave van de verschillende aspecten van een bepaald vraagstuk resp. op de consequenties van verschil lende mogelijke oplossinqen, dan op een conclusie t.a.v. de bij voorkeur te kiezen oplossinq. Zulks geldt ook voor het eventuele advies van de accountants bij de formulering van de opdrachten sub a.

Ik meen op deze plaats met deze korte opmerkingen over dit subtiele vraagstuk te kunnen volstaan.

7. Is de hiervoren geschetste organisatie van de contröle onder de huidige omstandigheden practisch te verwezenlijken?

Ik moet erkennen, dat dit laatste punt van mijn beschouwing een penibele vraag is.

Als ideaal zou te beschouwen zijn de toestand, waarin elk van de circa 400 , onder de E.G.K.S. ressorterende bedrijven reeds was voorzien van een bedrijfsaccountant, en waarbij al deze accountants aan hun verantwoordelijkheid zouden beantwoorden, door hun arbeid te verrichten volgens doeltreffende, vaktechnische onderzoekingsmethoden, ten aanzien waarvan op de principiële punten geen belangrijke verschillen van mening zouden bestaan. 
Dit ideaalbeeld zou moeten worden gecompleteerd met de veronderstelling, dat in het maatschappelijk verkeer, en in het bijzonder onder de ondernemingshoofden, een zuiver begrip heerste omtrent de inhoud van de functie van de openbare accountant en de formele wijze, waarop deze haar vervulling vindt in de verklaring.

Ook dàn zou nog een directe waarborg moeten worden geschapen tegen individuele verschillen in de beroepsuitoefening, welke nu eenmaal steeds mogelijk zijn en welke door een beroepstuchtrechtspraak - die uiteraard een repressief karakter heeft - niet kunnen worden voorkomen, ja zelfs: welke daaraan grotendeels onttrokken blijven.

Hoever zijn wij echter binnen het gebied van de E.G.K.S. van dit ideaal verwijderd!

Zelfs in Nederland, waar het georganiseerde beroep op een ervaring en ontwikkeling van meer dan een halve eeuw kan bogen, en waar de opleiding, de vakbeoefening en de beroepsrechtspraak, althans binnen het Nederlands Instituut van Accountants (N.I.v.A.) en de Vereniging van Academische Gevormde Accountants (V.A.G.A.), in het algemeen gesproken op een hoog peil staat, tiert de beunhazerij nog welig en is het inzicht van het "verkeer" in de maatschappelijke functie van de accountant stellig nog niet volgroeid.

Hoeveel minder gunstig is deze toestand echter in de andere landen van de Gemeenschap (uitgezonderd wellicht Duitsland), waar eerst in de allerlaatste tijd door middel van wettelijke regelingen een accountantsstand ,uit de grond wordt gestampt" en waarbij wel blijkt, dat in deze landen de historische achterstand in de opvattingen van het maatschappelijk verkeer zeer groot is.

Het zou derhalve m.i. van weinig realiteitszin getuigen, indien de inschakeling van de openbare accountants langs een blind-formele weg werd geëntameerd via de verenigingen en organisaties, welke thans in de verschillende landen bestaan, omdat het werkelijk "niveau" daarvan zeer verschillend is. $\mathrm{Er}$ is zelfs onlangs een Europese organisatie gesticht, waarbij het N.I.v.A. en V.A.G.A. zich om begrijpelijke redenen niet hebben aangesloten. Ik ben er persoonlijk van overtuigd, dat deze Nederlandse organisaties een geheel ander standpunt zouden innemen en in de toekomst wellicht zullen innemen, indien het beroepspeil in de andere landen vergelijkbaar was resp. binnen een hopelijk niet al te lange tijd zal zijn.

Wat dit laatste betreft, zou een grote stimulans kunnen uitgaan van een doelmatige opzet van de contrôle door de E.G.K.S. Het komt mij voor, dat daarbij, behalve de inschakeling van de gekwalificeerde bedrijfsaccountants in Nederland en Duitsland, de bijzondere steun van à titre personnel gekozen accountants van groot nut zou kunnen zijn, niet alleen wat betreft de contrôle bij de andere bedrijven, doch ook ter advisering van de H.A., inzake de organisatie van de contröle.

Ik zou mij zelfs kunnen indenken, dat een of meer vooraanstaande public accountants tijdelijk bij de H.A. worden geaccrediteerd, onder het volledige behoud van hun zelfstandigheid, teneinde de $H$.A. te adviseren omtrent de inschakeling van de bedrijfsaccountants in Nederland en Duitsland, en, na zorgvuldig onderzoek naar de persoon en de wijze van vakbeoefening, ook in de andere E.G.K.S.-landen.

Voorts zouden deze geaccrediteerde accountants een „comité" kunnen vormen, teneinde de, individueel verschillende, algemene contrôle-methoden t.a.v. de principiële punten te toetsen en de onderzoekingsobjecten 
en -methoden in bijzondere gevallen te bepalen. Dit "comité" zou tevens de H.A. kunnen adviseren omtrent de formulering van de opdracht c.q. van de af te leggen verklaring (zie punt 6). Een en ander in overleg met de accountants, die de bedrijven controleren.

Ik wil deze studie besluiten met te verwijzen naar de woorden van de heer Jean Monnet, vermeld in de aanhef van dit artikel. Tot de ,instellingen" daar genoemd, behoort de functie van de openbaar accountant. Ook deze functie, mits doelmatig opgevat en beoefend, is een waarlijke peiler van onze beschaving.

\section{RESUME}

L'évolution actuelle de notre société, dont la création du Pool de l'acier et du charbon est une preuve tangible, ouvre de nouveaux débouchés à l'activité des experts-comptables. Et cela ne regarde seulement les experts eux-mêmes, mais aussi tous ceux qui peuvent utiliser avec profit leurs services.

L'auteur passe d'abord en revue quelques problèmes professionnels et notamment:

- les connaissances exigées d'un expert-comptable (elles doivent être avant tout fondées sur l'économie d'entreprise avec application aux cas concrets en particulier à tout ce qui touche au contrôle);

- sa fonction spécifique (dont l'essence réside dans l'objectivité);

- le rapport d'expertise comptable (qui est l'instrument de la fonction):

- la notion de „partie" (c'est-à-dire tous ceux qui ont intérêt au jugement de l'expert);

- les interêtts dits divergents (ici, le rapport d'expertise devient d'une importance primordiale):

- et la différence entre l'expert-comptable indépendant et l'expertcomptable en service (ce dernier étant sous la dépendance d'autrui, son objectivité pourrait être mise en cause).

L'auteur fait remarquer enfin que la position de l'expert ne change pas formellement ni matériellement lorsqu'une des parties est un „pouvoir public", c'est-à-dire un organe chargé des intérêts collectifs.

Ensuite l'auteur délimite le domaine de ses recherches en analysant le traité du Pool enfin de dégager les fonctions qui pourront en découler pour les experts-comptables. En effet, la Haute Autorité se doit de contrôler les entreprises soumises à sa juridiction quant à la vérification de leurs chiffres d'affaires pour le calcul des impôts, pour le contrôle des prix, sous certaines conditions pour le contrôle des débouchés, et pour le calcul du prix de revient. Enfin elle doit rassembler les données indispensables à la réglementation du marché.

L'auteur fait observer cependant que la Haute Autorité doit à son tour rendre des comptes à l'Assemblée et qu'elle doit aussi s'entendre avec le Conseil des Ministres et le Comité consultatief, tandis que dans certains cas la Cour de Justice est appelée à départager les entreprises et les organes du Pool. Pourtant, dans tous ces rapports complexes on a toujours besoin de mêmes données, c'est-à-dire, des phénomènes se manifestant à l'intérieur des entreprises ou des rapports entre elles. Par conséquent, des vérifications faites par l'expert-comptable pourront servir à plusieurs fins. 